\title{
Black "marble" in the Polish architecture - characteristics and possibility of its provenance determination: the case of the Dębnik limestone
}

\author{
Mariola Marszałek \\ AGH University of Science and Technology, Department of Mineralogy, Petrography and Geochemistry; al. Mickiewicza 30, \\ 30-059 Krakow, Poland; e-mail: mmarszal@agh.edu.pl \\ (C) 2014 Authors. This is an open access publication, which can be used, distributed and reproduced in any medium according \\ to the Creative Commons CC-BY 4.0 License requiring that the original work has been properly cited.
}

Received: 2 September 2013; accepted: 5 June 2014

\begin{abstract}
Black limestone, also known as black "marble", was widely used in the Polish small-scale architecture and art of the $17^{\text {th }}$ and $18^{\text {th }}$ centuries. Besides the Devonian limestone from Dębnik near Krakow, also popular were the Netherlandish (Wallonian), Devonian to Carboniferous limestones from the Meuse River and Schelde River valleys. This paper deals with the possibility of identifying the rocks imported to Poland. Macroscopic similarities between the Netherlandish rocks and some Dębnik limestones have been highlighted for the oldest Carmelite quarry in Dębnik, exploiting the best stones. The analyses include: optical microscopy, scanning electron microscopy with EDS, X-ray diffraction, X-ray fluorescence and isotope ratio mass spectrometry $\left({ }^{13} \mathrm{C}\right.$ and ${ }^{18} \mathrm{O}$ stable isotopes). Carboniferous limestones from Netherlands can be identified within and distinguished from the Dębnik limestone in the macroscopic observations. Differences, depending on the varieties, are associated primarily with the presence of white calcite fragments of fossils, calcite veins intersecting the rock in all directions or hardness of the limestones. Deeply black Devonian limestones from Wallonia and Dębnik without macrofossils and calcite veins differ in microscopic observations considering their texture, type of microfossils and inventory of non-carbonate components. The characteristic graying and whitening of the black limestones has also been discussed as a possible feature of rock provenance.
\end{abstract}

Keywords: black limestone, provenance, petrography, stable isotope geochemistry, deterioration, Poland, Belgium

\section{INTRODUCTION}

Black limestones, due to their decorativeness and capability of taking good polish and also known since centuries as black "marble", became in Poland, particularly in Mannerist and Baroque times, important materials in stone-masonry. These rocks were obtained from quarries of the Devonian limestones located in the village of Dębnik not far from Kraków, and from Kajetanów (Zechstein rocks) in the Holy Cross Mountains. Black limestones were also imported from the
Netherlands [present-day Belgium (Wallonia)], mainly from the quarries of Lower Carboniferous rocks located in the valleys of the Meuse River (Dinant, Denée, Namur) and the Schelde River (Tournai). In the further text these rocks will be called the Netherlandish limestones, according to the then (the $16^{\text {th }}-18^{\text {th }}$ centuries) territorial division. Consequently, their names will be given according to current sources and the present names of localities (references cited are mostly from the beginning of the $21^{\text {st }}$ century). Source studies initiated in recent years by Polish historians of art 
successively sort out our knowledge on the import and applications of the Netherlandish black "marbles" in Poland between the Middle Ages and the end of the $18^{\text {th }}$ century (Szmydki 1999, 2000, 2012, Wardzyński 2008, 2010). However, the macroscopic differentiation of the limestones ("marbles") generally can be difficult or impossible, especially if they are pure and of the same age (Groessens 1997, Brilli et al. 2010). It happens that the same artifacts are described in some papers as made of the Dębnik limestones, in others as made of Netherlandish limestones, for instance the $17^{\text {th }}$-century chapel of the Koludzki family in the Gniezno cathedral in N Poland (vide Tatarkiewicz 1953, Niemcewicz 2005, Wardzyński 2008, Sylwestrzak \& Kachnic 2010). Identification of the provenance of building and decorative limestones based on the analyses of quarrying archive materials, unfortunately sometimes unreliable and containing gaps, may be supported by applying a spectrum of interdisciplinary methods, particularly petrographic, chemical and isotope $\left({ }^{13} \mathrm{C}\right.$ and $\left.{ }^{18} \mathrm{O}\right)$ determinations used in Earth sciences. They can reveal possible differences among limestones coming from various quarries and being of different geological ages. As a result, combined petrographic characteristics, isotope ratio mass spectrometry and, if available, electron paramagnetic resonance (EPR) techniques have appeared to be important analytical tools (Pintér et al. 2004, Polikreti et al. 2004, Brilli et al. 2010, 2011).

Considering the scarcity of papers containing characteristics of the Netherlandish black limestones applied in the Polish architecture, the author has presented their mineralogical and petrographic features. Also domestic black limestones applied in the Polish architecture have been characterized and the data supplemented with the results of petrographic, chemical and isotopic $\left({ }^{13} \mathrm{C}\right.$ and ${ }^{18} \mathrm{O}$ stable isotopes) studies of the Dębnik limestone. It is the intention of the author to compare the features of the imported and domestic black limestones used in Poland from the $16^{\text {th }}$ to the $18^{\text {th }}$ centuries, which can be of help in identifying rock provenance, and to create in the future a kind of a database, which could help in distinguishing the limestones applied as ornamental or building stones in the Polish architecture.

\section{BLACK LIMESTONES USED IN POLAND}

\section{Historical evidence}

The use of Netherlandish limestones from the end of the $16^{\text {th }}$ century to the $18^{\text {th }}$ century in the lands of the Teutonic Order's state, in the city of Gdańsk and elsewhere in Pomerania, and also in the remaining northern lands of the Commonwealth of Poland and Lithuania, was discussed in detail, among others, by Szmydki $(1999,2000,2012)$ and Wardzyński $(2008,2010)$. Of the Netherlandish limestones, the last author mentioned the homogenous, the Upper Devonian the Noir Belge (also known as the Noir de Namur; Namur region the quarries Grandes-Malades, Bouge, Mazy and Golzinne), the Visean Noir de Dinant, Bleu Belge and Calcaire de Meuse (Meuse valley - around the town of Dinant), the Pierre de Tournai and Noir de Tournai (Hainaut region - the villages Chercq, Calonne, Antoing) stones. However, based on his description of the last stone "loamy-silicon (sic!) bioclastic limestone", it may rather represent a limestone of the Tournaisian age (Nijs 1992, Storemyr et al. 2007). The tombstone of Arnold Lishoren in the post-Cistercian church in Chełmno-on-the Lower Vistula dated back to the second half of the $13^{\text {th }}$ century, is regarded as the first use of the Netherlandish Noir de Tournai limestone in the historic lands of Poland (Wardzyński 2008).

The limestones imported from the Netherlands did not reach, however, southern Poland with Kraków included, where the local limestones from Dębnik were the stones of choice. The oldest reference to the quarries of the latter comes from 1415 (Rajchel 2004, Wardzyński 2008). As the first prestigious works made of Dębnik limestones in the years 1627-1629 are regarded the reliquary altar of Saint Stanislaus and the tombstone of bishop Marcin Szyszkowski, both in the Wawel cathedral in Kraków. Limestone quarrying at Dębnik began in the late Middle Ages and expanded in the first half of the $16^{\text {th }}$ century (the reign of Sigismund I the Old), but more advanced stone-mason operations started only after the next houndred years, i.e., in the early $17^{\text {th }}$ century (involvement of the Firlej family during the reign of Sigismund III) and lasted till the end of the $18^{\text {th }}$ century. In that last period, in the vicinity of the Dębnik village were active 
fifteen or so limestone quarries (Tatarkiewicz 1953, Narkiewicz \& Racki 1984) (Fig. 1). The biggest, oldest and with the stones of the best quality, owned since 1644 by the nearby monastery of the Calced Carmelites, has been named the Carmelite quarry. The Dębnik limestone was known also as the Schwarzer Marmor von Dembnik, the Korallenkalk von Siedlec, the Schichten der Siwa Góra, the Amphipora-Banke des Karmeliterbruches der Czarna Góra and the Dębnik marble (Tatarkiewicz 1953, Bromowicz 2001). Beginning from ca. 1630, the domination of the Dębnik limestones became evident in the Polish sculpture and architecture, resulting in successive replacing the Netherlandish stones and squeezing them out of the market. It was due to an overall political and economic situation in Europe that the import of the limestones from the distant area of the Meuse and Schelde rivers dwindled away and eventually disappeared. In this way, the black Dębnik limestones reached an immense popularity in Poland, having been used by leading Italian artists till as long as the end of the $18^{\text {th }}$ century (Wardzyński 2010).

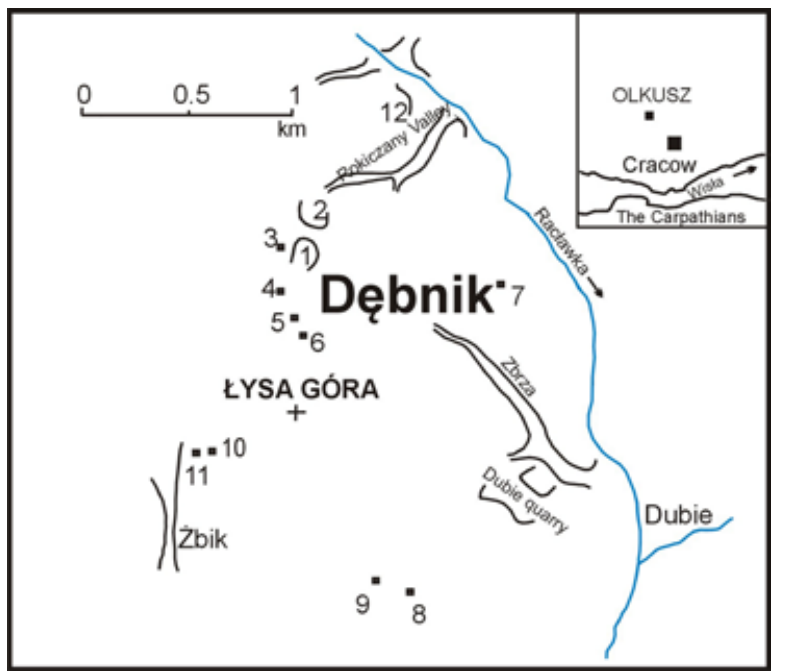

Fig. 1. Location of black limestones in the Dębnik region: 1 - Carmelite quarry, 2 - new Dębnik quarry, 3 - Tumidalski quarry, 4-6 - small exposures in the Dębnik village, 7 - Marmurowa Góra quarry, 8, 9 - exposures close to the Siedlec village, 10, 11 - quarries close to the Żbik village, 12 - exposures in the Racławka valley (after Łaptaś 1982 vide Narkiewicz \& Racki 1984, altered by the author)

Other domestic stone materials used in masonry and sculpture ca. 1600 include also the rocks from the Holy Cross Mountains in central Poland: the Permian bituminous limestones from
Kajetanów (Święcicki 1874, Czarnocki 1923, 1952, Kozłowski et al. 1971, Kowalczewski 1972, Niemcewicz 2005) and the Devonian limestones from Górno and Łagów (Wardzyński 2012). Their quarrying started around the year 1600 and continued over the next centuries as it was in Dębnik. However, the black limestones from the Holy Cross Mountains were used on a very limited, local scale, contrary to other famous, color and marble-like limestones from this region, among others the "marbles" from Morawica, Bolechowice and Miedzianka; the brecciated limestone with thick calcite veins from Zelejowa hill called Różanka zelejows$k a$; and the conglomerate from Jerzmaniec called Zygmuntówka. However, without any doubts, the domination of the Dębnik limestones among domestic black limestones is out of question.

The Dębnik limestone was applied both as a structural and decorative stone in tombstones and epitaph tablets, inner and outer portals, but also in altars, railings, floor slabs, baptismal fonts, even complete chapel interiors, etc. (Fig. 2). The sculptors working in Dębnik produced countless works of small-scale architecture that spread not only all over the Commonwealth of the Two Nations as Poland and Lithuania were then called, but also were widely exported to neighbouring countries, e.g., Germany (Frankfurt am Main) and Austria (Vienna, Graz, Salzburg) (Tatarkiewicz 1953, Tołkanowicz 2001, Rajchel 2004, Niemcewicz 2005, Sylwestrzak \& Kachnic 2010, Wardzyński on-line).

Black marble-like limestones and marbles were also commonly used in baroque architecture all over Europe. Some occurrences of such rocks are well known on a regional scale, among others in Germany (Aachen: Aachener Blaustein - Lower Carboniferous, Zehnder 2006, Schupbach near Limburg: Schupbach Schwarz - Middle Devonian, Kirnbauer 2008), Bohemia (Moravia: Hády marble - Lower Carboniferous, Mrázek 1993), northern Italy (the region in the Southern Alps between Lake Como and Lake Garda: Calcare di Varena, Grigi Carnico, Nero di Rovere - Triassic, Marinoni et al. 2002, 2007), Spain (Vizcaya province near Marquiña: Negro Marquiña - Cretaceous, Alicante province, the Betic External Zone: Jabalina Stone - Triassic, Benavente et al. 2006) and Switzerland (the Northern Alps: Alpenkalk - Triassic and Jurassic; Zehnder 2006). 

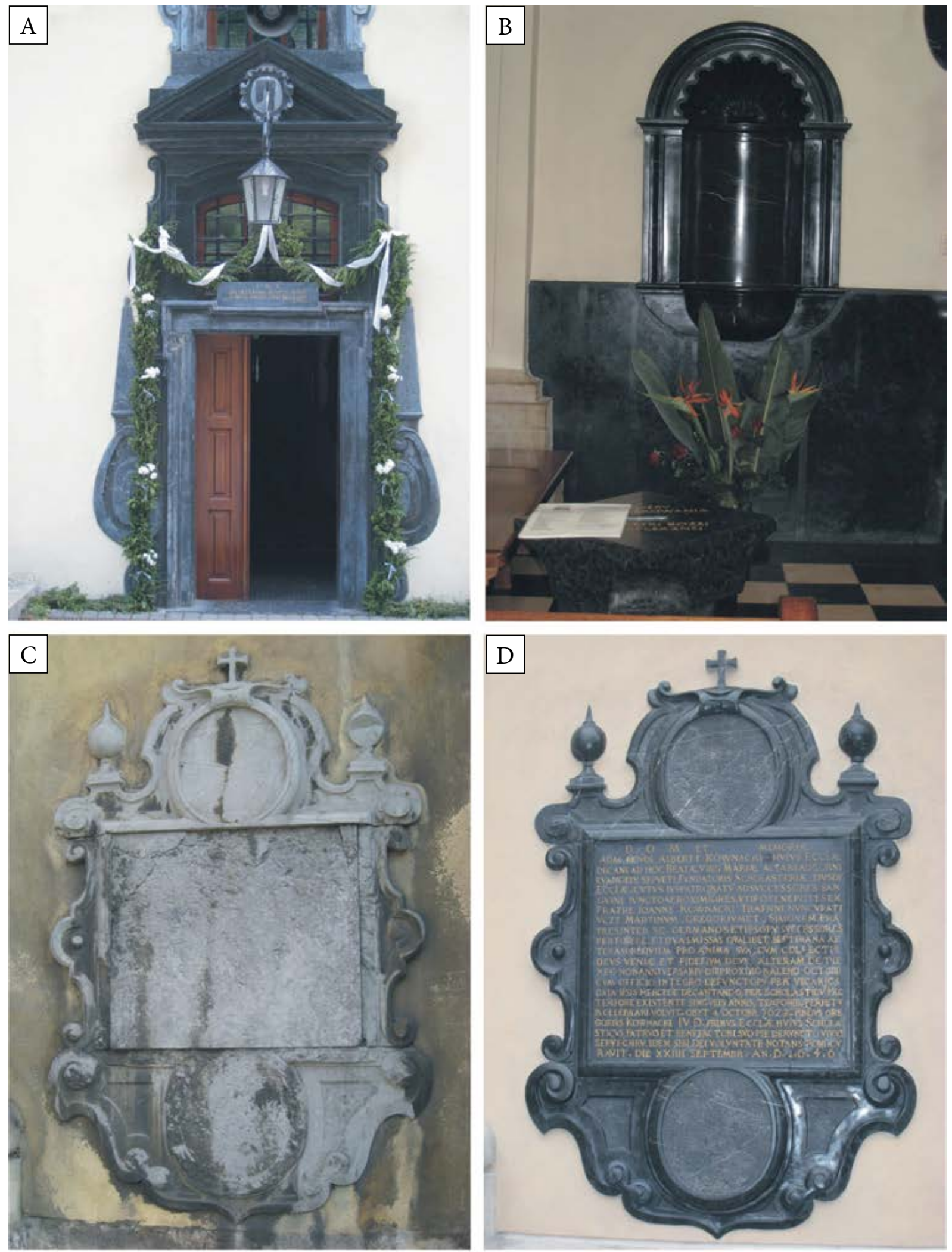

Fig. 2. The portal leading to the St Elijah Church (A); a lavetery in the St. Elijah Church in the monastery of the Calced Carmelites at Czerna (B); an epitaph tablet from the church of Calced Carmelites in Krakow (C and D): C) before conservation; D) after conservation 
However, opposite to limestones from the Netherlands (present-day Belgium) these rocks seem to have not been imported to Poland as no published records on their properties and practical use in the Polish architecture have been found so far.

\section{Characteristics of the limestones}

The Netherlands - Wallonia (present-day Belgium). The hard limestones in the southern Netherlands (present-day Belgium) from historical quarries formed from the Upper Devonian to Lower Carboniferous.

The Upper Devonian (Frasnian) black limestone belongs to the Rhisnes Formation cropping out in the Namur basin. The most famous Frasnian limestone is the thin-bedded (centimeters to decimeters thick) Marbre Noir de Golzinne (also known as Golzinne black marble, Noir de Mazy, Noir Belge, Noir fin), This homogeneous, almost perfectly deep black limestone is a very fine-grained mudstone in the Dunham (1962) classification, without macrofossils and calcite veins and described sometimes as the lithographic limestone. Rarely present microfossils represent ostracods, echinoids, pelecypods, sponges and algae. The rock contains mainly calcite with traces of bitumens, being almost a pure limestone. The stone is mined underground using the room-and-pillar method close to the Mazy village near Namur (Groessens 1997, Barquin et al. 2006, Coen-Aubert \& Boulvain 2006, Devleeschouwer et al. 2012).

Among the Carboniferous strata three lithostratigraphic units have been distinguished: Dinantian marine limestones (DSE - the Dinant sedimentation area), Namurian more terrigenous deposits (NSE - Namur sedimentation area), and Westphalian lacustrine sediments. The Dinantian is subdivided into the Tournaisian and the Visean, and more important rocks of these ages have been listed below. Black limestones ("marbles") were quarried mostly around the Meuse River and its tributaries (the Sambre, Mehaigne, Molignée, Bocq) and the Schelde River. Well known are the following limestones: the Calcaire de Meuse Vinalmont of the Visean age, the Noir de Denée of an early Visean age (Mottequin 2004, 2008), and the Petit Granit of the Tournaisian age, all of them from the Meuse River area; and the Noir de
Tournai of the Tournaisian age (Hance et al. 2006, Storemyr et al. 2007) from the Schelde River area (the Tournai region). The limestones of the Visean age show a typical association of foraminifera and algae. The Tournaisian limestones are characterized by the lack of foraminifera and the presence of bryozoans (Hance et al. 2006, Storemyr et al. 2007, Mottequin 2008).

The Visean black limestones are homogeneous, compact, pure and micritic; they contain above $95 \%$ calcite, sometimes $99 \%$, accompanied by traces of bitumens, sometimes pyrite, dolomite and quartz (Groessens 2001a, b, Barquin et al. 2006). The famous black limestones Noir de Dinant (also known as Marbre Noir de Dinant, Noir de Salet and in some papers the term Noir de Denée is also used) and Bleu Belge are extracted around the villages Dinant, Denée, Salet, Bioul (the Meuse valley), while the Calcaire de Meuse - Vinalmount (also known as Calcaire de Meuse, Pierre de Vinalmount) in the valley of the Mehaigne (a Meuse tributary). The black "marble" variety Noir de Dinant can be now inspected in a fossil protection deposit, in which besides the main foraminifera occur exceptionally well preserved although rare fauna, including notably large fishes, echinoids, crinoids, brachiopods, bryozoans, graptolites and cephalopods (Fraaye \& Werver 1990, Mottequin 2004, 2008, Devuyst et al. 2006). Its thickness varies from less than $1 \mathrm{~m}$ to several meters (the total thickness of the "marble" unit is close to 30 m; Devuyst et al. 2006, Mottequin 2008). The Bleu Belge type is characterized by calcite veins intersecting the rock in all directions, but because of fracturing is considered uneconomic. The thickness of its beds is ca. $20 \mathrm{~m}$. In petrographic terms, the stones are classified as bioclastic packstones/wackstones (Barquin et al. 2006). The Calcaire de Meuse - Vinalmount variety represents a wackstone/packstone oolitic limestone with foraminifera (macroscopically visible), corals, brachiopods and gastropods, but never with crinoids, which contains stylolite seams (Barquin et al. 2006). This dark gray to brown (after polishing) limestone occurs in thin beds.

The Tournaisian limestones from the Tournai region contain less calcite (75-80\%), a substantial amount of quartz $\left(16-20 \% \mathrm{SiO}_{2}\right)$, traces 
of dolomite, clay minerals, organic matter and pyrite; most of the rocks are slaty or laminated. Besides bryozoans and crinoids the fossils include also brachiopods, ostracods, corals and sponges. The compact gray (Pierre de Tournai variety) to dark gray and black (known as the Noir de Tournai), thick-bedded limestone (Hance et al. 2006) is classified as a bioclastic wackstone/packstone. The Petit Granit (also known as the Belgian blue limestone) from the Meuse River valley is a crinoidal limestone, whose numerous bioclasts exceed even $1000 \mu \mathrm{m}$. Besides crinoid trochites also bryozoans, brachiopods, ostracods and rugose corals are present, while locally peloid-rich patches occur. This is a compact wackstone/packstone, locally grading into a grainstone (Dreesen et al. 2007), but coarser-grained than the limestone from the Tournai region because of the presence of crinoid trochites. The thickness of its beds is about $30 \mathrm{~m}$ (Hance et al. 2006).

The disadvantageous features of the black limestones exposed to atmospheric conditions outside a building are decoloration (their original black color changes into gray or beige), while polished stones loose their shiny appearance. The least resistant, susceptible to destruction aggravated by their heterogeneity, are the Tournaisian limestones from the Tournai region. As a result, the stones take a crumbly and slaty appearance, however, the Meusean limestone may also delaminate. Therefore, such alterations are not diagnostic for differentiation of these rocks. This superficial phenomenon does not affect the inner part of the stone (Nijs 1992, Groessens 1993, Anderson \& Groessens 1996, Dreesen et al. 2007, Storemyr et al. 2007).

The most commonly used in Poland were the limestones quarried in the Meuse River valley, i.e., the Marbre Noir de Dinant, Bleu Belge, Calcaire de Meuse of the Visean age and Devonian Noir Belge (Wardzyński 2008). Their features: a deep black color, a long lasting polish, a presence of fossils (foraminifera, corals, crinoids and others) and white calcite veins seem to be characteristic.

Poland - the Holy Cross Mountains. Bituminous, pelitic limestones with the deep and uniform black color occur in the Holy Cross Mountains (central Poland) at Kajetanów and are of the Upper Permian (Zechstein) age. Another, dark gray variety with calcite veinlets from this locality was also mentioned (Święcicki 1874, Czarnocki 1923, 1952, 1965, Kozłowski et al. 1971, Kowalczewski 1972). Brachiopods (Productus horridus), bryozoans and bivalves are the fossils present in the rock. The bed thickness is ca. $2 \mathrm{~m}$, unfortunately due to unfavorable geological and mining conditions and the demands of groundwater protection quarrying already stopped in 1905 (Czarnocki 1923, 1952, 1965) cannot be restarted. Other building and decorative stones used already at the beginning of the $17^{\text {th }}$ century (Wardzyński 2012, Wardzyński on-line) include Devonian bituminous, fine-detrital, flag-like, thin-bedded limestones from Górno (Frasnian) and gray to brown-gray dolostones and limestones from Łagów (Frasnian, Givetian). They reveal the presence of fauna, mainly brachiopods, amphipores and stromatopores, while their fractures are filled with white calcite (Czarnocki 1923, 1952, Kotański 1959, Kozłowski et al. 1971, Peszat 1980, Bromowicz \& Figarska-Warchoł 2012).

Poland - the Dębnik village near Krakow. The deposits of black limestone occur in the southern part of Poland, about $20 \mathrm{~km}$ west of Kraków in the vicinity of the Dębnik village, and are of the Middle Devonian, i.e., Givetian and Frasnian age (Narkiewicz \& Racki 1984, Baliński 1989, Bednarczyk \& Hoffman 1989).

With regard to the ornamental properties of the Givetian Dębnik limestone, its three varieties have been distinguished: the homogeneous, micritic one; the micritic one with fossils; and the non-homogeneous, black and dark gray detrital one, laminated in places, intercalating with the pelitic variety (Fig. 3). They make about 23\%, 36\% and $41 \%$ of the profile, respectively. The average thickness of the limestone beds ranges usually between $40 \mathrm{~cm}$ and $60 \mathrm{~cm}$ (Bromowicz 2001). The Frasnian limestones are developed as nodular and wavy varieties.

The Dębnik limestones reveals some color changes, from black to dark gray to ash gray. The color may be uniform or variable, giving the rock spotty or cloudy patterns. Also characteristic are concentric patterns of various shades of gray. The variable coloration occurs mainly in the nodular or wavy limestones and results from selective lithification and partial dissolution of calcium carbonate during early diagenesis (Bednarczyk 
\& Hoffman 1989). The decorative features of the Dębnik stones include besides the black color, an occasional presence of fossils that are paler than the enclosing rock, sometimes almost white, and/ or thin, nearly white calcite veins. The fossils identified include mainly hydrozoans: Amphipora sp. and Stromatopora sp., also corals, brachiopods, crinoids and gastropods (Bednarczyk \& Hoffman 1989, Bromowicz 2001). The rocks represent relatively pure limestones containing major calcite and traces of dolomite. Non-carbonate components include K-feldspar, smectite, illite, subordinate pyrite and organic substances, as well as traces of detrital quartz and hydromuscovite (Marszałek \& Muszyński 2001).

The black color of the Dębnik limestone has been thought to result from an admixture of bitumens (Gradziński 1972, Kozłowski \& Magiera 1989, Lewandowska 1998, Marszałek \& Skowroński 2010) or, according to Bednarczyk \& Hoffman (1989), of pyrite. The stone releases a smell of petroleum if hit with a hammer. The content of organic substances in the whole rock was estimated at $0.30 \mathrm{wt}$ \% TOC (total organic carbon) that corresponds to $4.4 \mathrm{wt}$. \% TOC in the HCl-insoluble fraction; they exhibit the features of the type III kerogen, i.e., the kerogen derived from humic organic matter of probable algal and bacterial origin (Marszałek \& Muszyński 2001, Marszałek 2007). The organic compounds represent a mixture of fatty acids, saturated and non-saturated n-alkanes $\mathrm{C}_{16}-\mathrm{C}_{20}$, aromatic hydrocarbons and polycyclic hydrocarbons (Marszałek 2007). The total amount of pyrite in the Dębnik limestone is about 2 wt. \% (Marszałek \& Muszyński 2001, Marszałek \& Skowroński 2010).

\section{MATERIALS AND METHODS}

Considering some macroscopic similarity of the massive, homogenous, micritic Dębnik limestones with the deep black color to the Noir Belge limestones from the Netherlands, the author focused only on this variety of the Dębnik rocks. The non-uniform nodular and laminated limestones of Dębnik are sufficiently characteristic in hand specimens to be positively identified.

The materials analysed were collected in the Carmelite quarry, which provided the stones of the best quality (Fig. 3). Their nodular and laminated structures are generally very weakly expressed, therefore dominate pelitic limestones with scanty fauna of gastropods and crinoids, and local accumulation of Stromatopora sp., Amphipora sp. and corals.

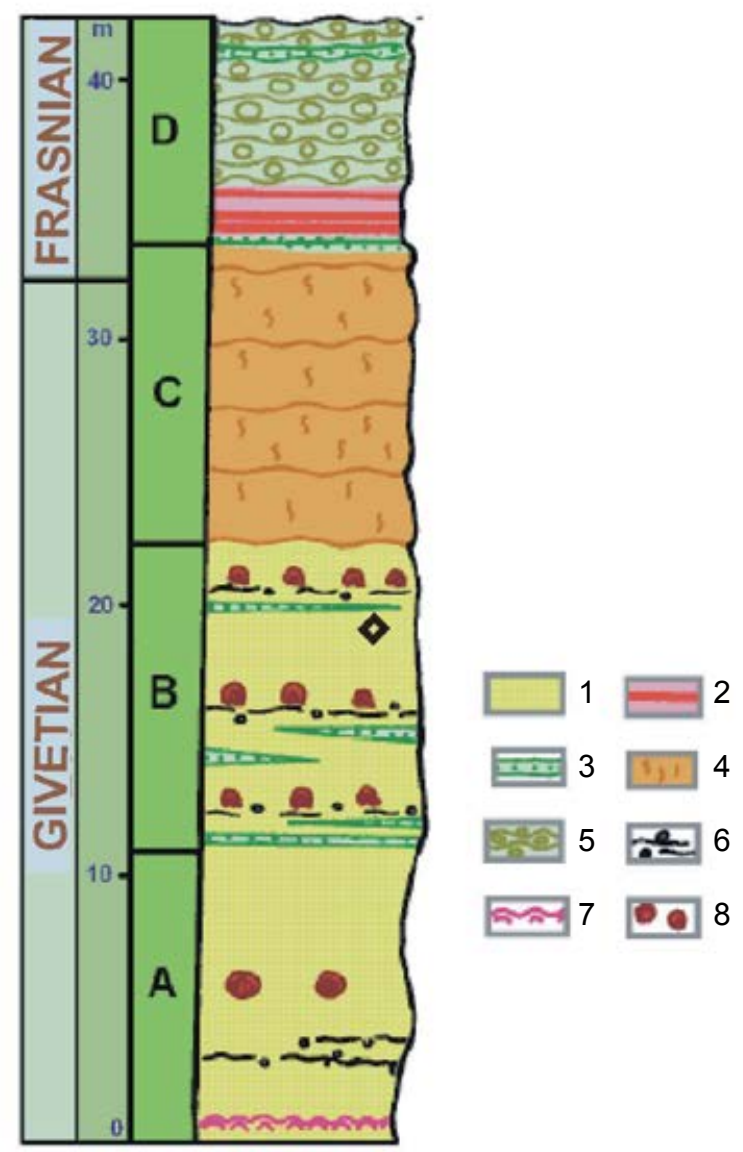

Fig. 3. Simplified profile of the Dębnik limestones (after Bednarczyk \& Hofman 1989, altered by the author): 1 - pelitic limestones, 2 - marls, 3 - detrital limestones, 4 - bioturbated pelitic limestones, 5 - nodular limestones, 6 - erosional surfaces, 7 - stromatolites, 8 - stromatoporoids. The Carmelite quarry include the $A$ and $B$ levels of the profile, samples were taken from the B level (symbol $\diamond)$

Both fresh (12 samples) and weathered (5 samples) limestones were taken, the latter selected basing on changes of their original black color into gray or even white. The variety with color alterations was used for studying changes of the texture in the outer stone layers.

The petrographic characterization was carried out using an Olympus BX 51 optical microscope and a scanning electron microscope FEI Quanta 200 FEG with an energy dispersive spectrometer EDAX. The mineral composition was also 
analysed using X-ray powder diffraction with a Philips X'Pert APD diffractometer. X-ray fluorescence was employed in chemical determinations using a Philips PW 2400 (samples with the symbol KS) and a Rigaku 25X Primus II (samples with the symbol DK) analysers.

Optical and scanning electron observations were made on universal polished thin sections cut perpendicular to the stone surface. Additionally, broken surfaces of inner (non-weathered) and outer (weathered) parts of the samples were studied using the SEM method.

Oxygen and carbon isotopes were determined by isotope ratio mass spectrometry at the Stable Isotope Laboratory of the Goethe University in Frankfurt am Main, Germany. The samples with signs of weathering and with secondary calcite veins have been excluded from the analyses. Ten samples were analysed using a Gas Bench II hooked up to the continuous flow inlet system of a MAT 253 gas source mass spectrometer following the methods outlined by Spoetl \& Vennemann (2003). For data correction, the Carrara marble calibrated against the NBS-18 and NBS-19 US standards was used as an internal standard. A precision of $1 \sigma$ standard deviation was usually higher than $\pm 0.06 \%$ in the carbon isotope and $\pm 0.08 \%$ in the oxygen isotope analyses. The results are expressed in $\delta \%$ in relation to the international V-PDB scale.

\section{RESULTS}

The samples of the Dębnik limestone represent a pelitic rock, without macroscopically visible nodular texture and wave bedding except for the sample DK2-2, which has very weakly expressed lamination. Sometimes they occasionally reveal small veins probably of secondary calcite. Fresh limestones are black, but their outer layers exposed to atmospheric condition have been bleached.

The mineral composition and petrographic characteristics observed in thin sections are
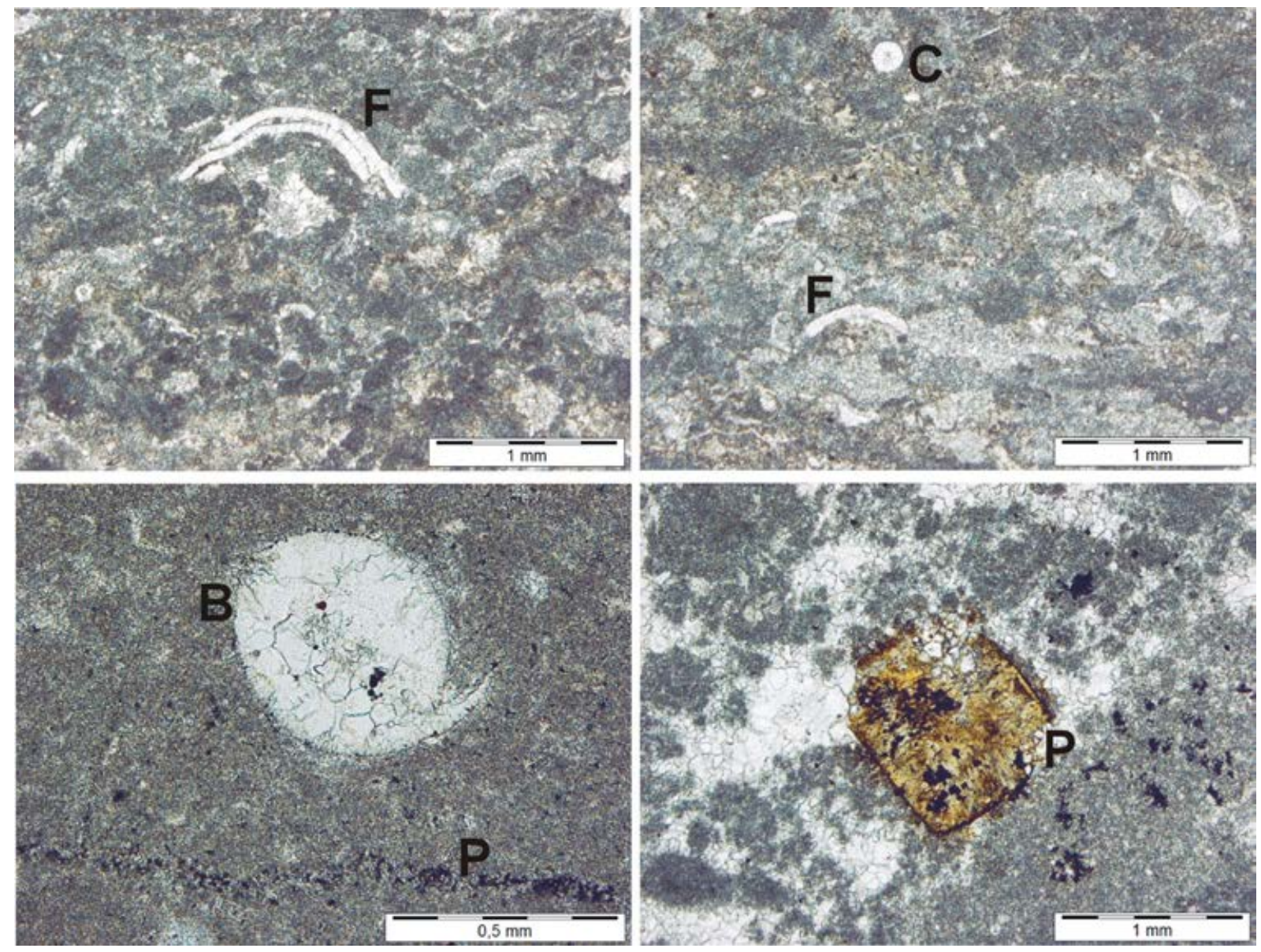

Fig. 4. Microphotographs of a Dębnik limestone sample: biomicritic wackestone with fragments of fossils. Abbreviations of some important features: $B$ - brachiopods, $C$ - corals, $F$ - shell fragments (brachiopods, ostracods, pelecypods), P - Pyrite. One polar 
similar in all the samples analysed, although small differences described below could be observed. The components of the samples established in XRD analyses include calcite and traces of dolomite.

Based on the petrographic observations in the thin sections (Fig. 4), the limestone can be classified as wackstone (Dunham 1962) with bioclasts and peloids. Microscopy reveals very weak, subtle lamination, expressed in a directional arrangement of bioclasts and a distribution of dispersed organic matter and, probably, pyrite. The parallel laminae of intercalating darker micrite and lighter microsparite can exceptionally be bent or lensoidal. Those enriched in organic matter and bioclasts are composed of micrite, those without or with minor amounts of these components are developed as microsparite. In sample DK2-2 lamination is slightly more distinct. It is of the microbial, grading into peloidal character (peloidal stromatolite).

The grain components of the limestones are mainly bioclasts. The fossils include mollusc shells, brachiopods, corals, and hydrozoans (Stromatophora sp. and Amphipora sp.). The bioclasts are small, most of them below $0.5 \mathrm{~mm}$, and commonly exhibit traces of mechanical destruction. The samples occasionally display also a presence of peloids, usually oval and very small, mainly
$30-80 \mu \mathrm{m}$ in size, cemented by microcrystalline calcite. In sample DK2-5, bioclasts and peloids with occasional nodules $0.5-1 \mathrm{~mm}$ in diameter are accompanied by fine intraclasts. In some places there are zones with a denser packing of bigger, $0.5 \mathrm{~mm}$ to ca. $1 \mathrm{~mm}$, the clasts cemented with sparse microsparite and even fine sparite. The thin sections also reveal the presence of stylolites with low amplitudes. They are healed mainly by iron oxyhydroxides and pyrite. Microveins of sparitic calcite are sometimes also present, in sample DK2-2 being more frequent than in other samples.

The non-carbonate components include the aforementioned opaque organic matter concentrated parallel to the bedding, small cuboidal crystals of pyrite, and iron oxyhydroxides. Pyrite is dispersed throughout the rocks, but often concentrates close to organic matter. Its single, bigger crystals with a size of ca. $1 \mathrm{~mm}$, sometimes showing signs of weathering, occur occasionally. The siliciclastic components are not visible in the thin sections probably because of their micro- to cryptocrystalline development.

The chemical analyses confirm the purity of the Dębnik limestone (Tab. 1). The rock is composed mainly of $\mathrm{CaO}$ (51.13-55.72 wt. \%), accompanied by minor amounts of $\mathrm{SiO}_{2}, \mathrm{Al}_{2} \mathrm{O}_{3}, \mathrm{~K}_{2} \mathrm{O}$ and $\mathrm{MgO}$.

Table 1

Chemical composition and stable isotopes of the limestones from the Carmelite Quarry

\begin{tabular}{|c|c|c|c|c|c|c|c|c|c|c|}
\hline & DK2-1-1 & DK2-1-2 & DK2-1-3 & DK2-1-4 & DK2-1-5 & DK2-2 & DK2-3 & DK2-5 & KS-1 & KS-2 \\
\hline \multicolumn{11}{|c|}{ wt. \% } \\
\hline $\mathrm{SiO}_{2}$ & 0.34 & 1.02 & 0.22 & 0.34 & 0.85 & 0.90 & 0.93 & 0.33 & 1.20 & 4.02 \\
\hline $\mathrm{Al}_{2} \mathrm{O}_{3}$ & 0.10 & 0.30 & 0.07 & 0.10 & 0.25 & 0.10 & 0.30 & 0.09 & 0.53 & 1.20 \\
\hline $\mathrm{TiO}_{2}$ & 0.00 & 0.00 & 0.00 & 0.00 & 0.00 & 0.00 & 0.00 & 0.00 & 0.04 & 0.00 \\
\hline $\mathrm{MgO}$ & 0.06 & 0.08 & 0.05 & 0.06 & 0.05 & 0.45 & 0.10 & 0.05 & 0.85 & 1.02 \\
\hline $\mathrm{CaO}$ & 55.42 & 53.99 & 55.64 & 55.72 & 55.19 & 55.53 & 55.36 & 55.35 & 53.92 & 51.13 \\
\hline $\mathrm{MnO}$ & 0.00 & 0.01 & 0.00 & 0.00 & 0.00 & 0.02 & 0.00 & 0.00 & 0.01 & 0.00 \\
\hline $\mathrm{Fe}_{2} \mathrm{O}_{3}$ & 0.13 & 0.33 & 0.04 & 0.08 & 0.25 & 0.16 & 0.23 & 0.15 & 0.29 & 0.99 \\
\hline $\mathrm{Na}_{2} \mathrm{O}$ & 0.06 & 0.00 & 0.02 & 0.00 & 0.00 & 0.00 & 0.00 & 0.00 & 0.00 & 0.04 \\
\hline $\mathrm{K}_{2} \mathrm{O}$ & 0.11 & 0.44 & 0.10 & 0.14 & 0.28 & 0.01 & 0.34 & 0.09 & 0.45 & 0.86 \\
\hline$\left(\mathrm{SO}_{3}\right)$ & 0.05 & 0.05 & 0.04 & 0.04 & 0.04 & 0.03 & 0.06 & 0.12 & 0.00 & 0.01 \\
\hline L.O.I. & 43.73 & 43.73 & 43.72 & 43.43 & 42.78 & 42.71 & 42.63 & 43.70 & 41.54 & 40.72 \\
\hline Total & 100.00 & 99.95 & 99.90 & 99.91 & 99.69 & 99.91 & 99.95 & 99.88 & 98.83 & 99.99 \\
\hline \multicolumn{11}{|c|}{$\%$} \\
\hline$\delta{ }^{13} \mathrm{C}_{\mathrm{V}-\mathrm{PDB}}$ & 0.55 & 0.16 & 0.41 & 0.40 & 0.49 & -2.33 & 0.35 & 0.13 & -0.06 & 0.39 \\
\hline$\delta^{18} \mathrm{O}_{\mathrm{V}-\mathrm{PDB}}$ & -8.20 & -6.25 & -8.52 & -11.39 & -4.89 & -18.04 & -5.45 & -5.93 & -5.35 & -7.94 \\
\hline
\end{tabular}

Note: $0.00 \mathrm{wt} . \%=$ a content below the respective detection limit. 
The calculated content of calcite is 91.2598.9 wt. \% with a mean of ca. 96 wt. \%, magnesium is bound in dolomite, while silica, alumina and potassium must be associated with

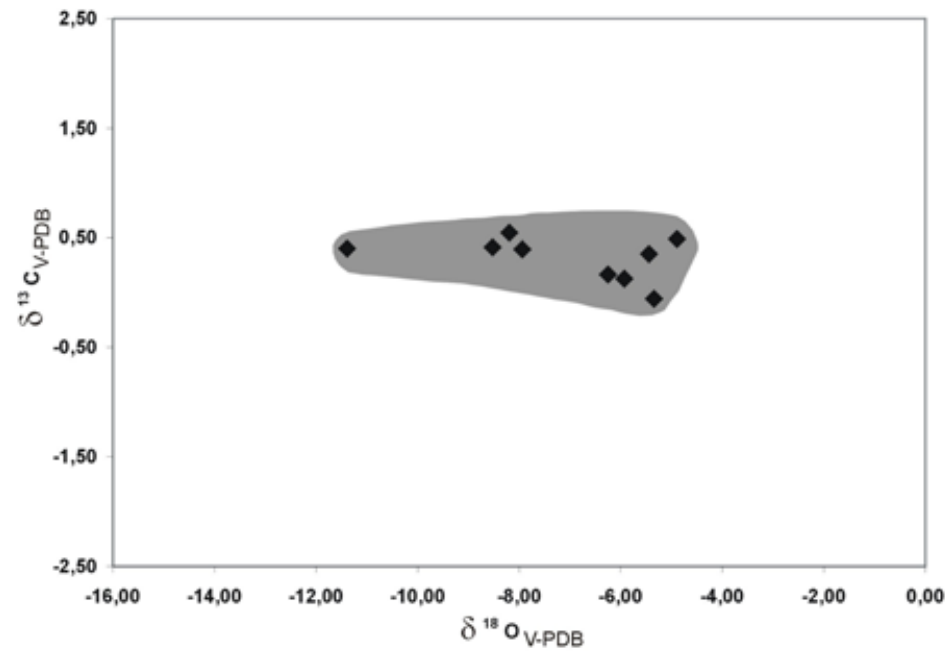

Fig. 5. Scatterplot of oxygen and carbon isotope data. Extreme values of the Dębnik quarry samples define the field border in the isotope ratio plot ("convex hulls" of Lesse, 1988) non-carbonate components, i.e., mainly K-feldspar and clay minerals (smectite and illite). Other elements occur in traces and often do not exceed $0.0 \mathrm{X}$ wt. \%.

The isotopic composition of the Givetian Dębnik limestone (9 samples) ranges from $-11.39 \% 0 \delta^{18} \mathrm{O}$ to $-4.89 \%{ }^{18} \mathrm{O}$ and $-0.06 \%{ }^{13} \mathrm{C}$ to $0.55 \%$ o $\delta^{13} \mathrm{C}$ (Tab. 1). Most of the samples analysed (8) reveal a similar isotopic composition, one sample (DK2-1-4) differs in its $\delta^{18} \mathrm{O}$ value. The tenth sample (DK2-2) have been excluded from consideration because of an unreliable determination, probably due to many microveins intersecting the rock. The results have been presented in the $\delta^{13} \mathrm{C}_{\text {V-PDB }}$ vs. $\delta^{18} \mathrm{O}_{\text {V-PDB }}$ cross plot diagram (Hudson 1977) (Fig. 5).

In SEM observations the weathered, bleached surface parts differ
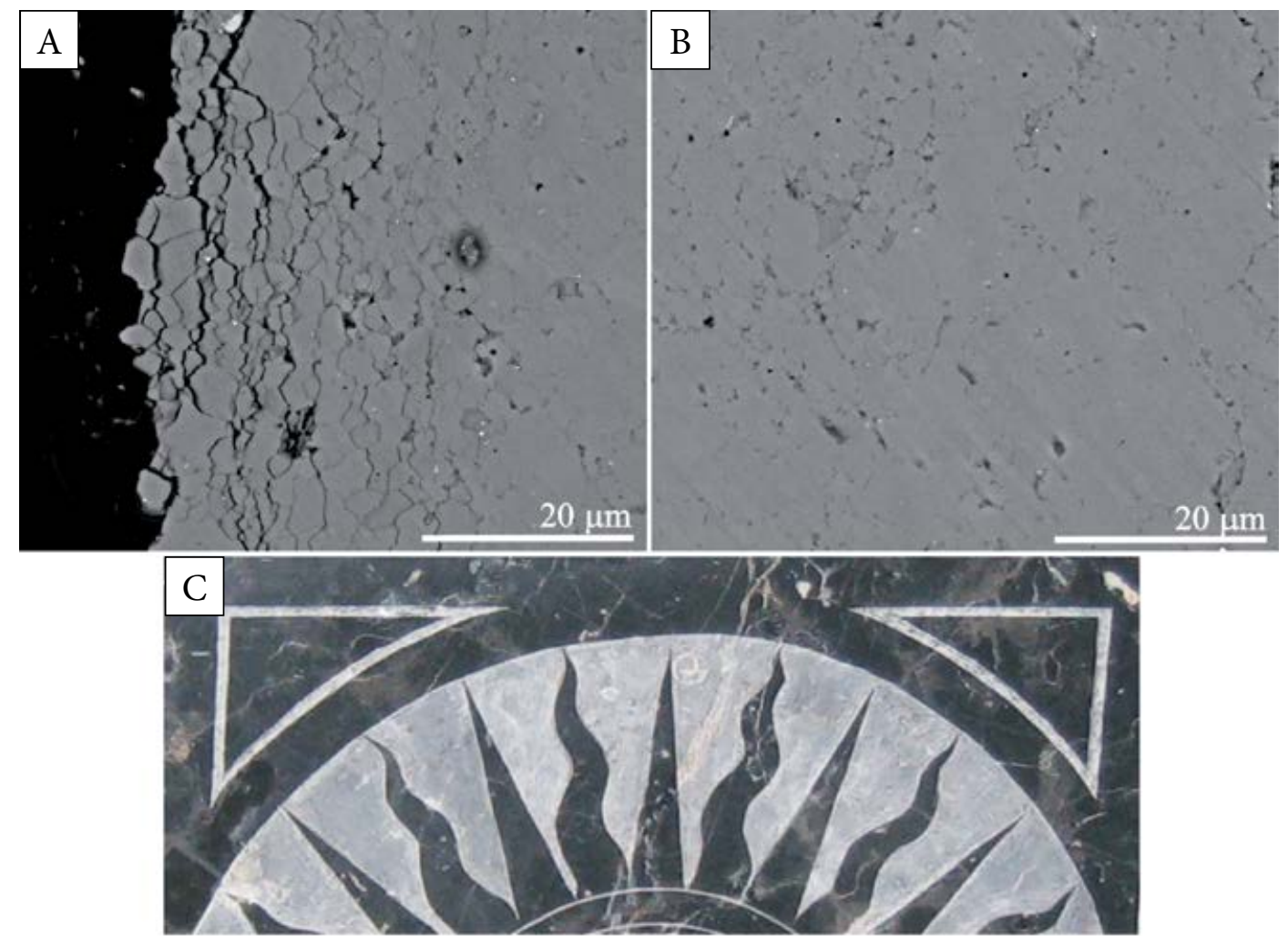

Fig. 6. SEM micrographs of a black limestone transversal section (A and B): A) highly fractured and weathered surface; B) inner part highlighting a compact structure of the stone and its low porosity. A fragment of decoration executed in the Dębnik limestones showing a contrast between the concave, matt and hammered into the pea-like pattern stone surfaces (light) and the polished and convex surfaces (dark) (C). Antependium of an altar in the St Elijah Church in the monastery of the Calced Carmelitan Fathers in Czerna 
from non weathered parts of the stone: they contain fine calcite grains with signs of leaching and a few anthropogenic particles. Additionally, the inner parts of the limestone display a compact structure and low porosity opposite to the weathered parts, the latter being characterized by discontinuities and intra- and inter-crystalline microfractures (Fig. 6A, B).

\section{DISCUSSION}

The hand specimen discriminating some varieties of black limestones of the Netherlands (Wallonia, present-day Belgium) from the black limestones of Dębnik (Poland), dominant in the Polish architecture, seems to be possible (Tab. 2).
The Meusean limestones: the black Noir de Dinant (packstone/wackstone; Dunham 1962), with millimeter-large, white calcite crystals that fill crinoid trochites, and with foraminifera (Mottequin 2004, 2008, Barquin et al. 2006, Boulvain \& Pingot 2013); the Calcaire de Meuse - Vinalmount wackstone/packstone, dark gray to brown, with characteristic oolitic texture and visible in hand specimens white calcite fossils of foraminifera (Barquin et al. 2006); and the black Bleu Belge with a blue tint and veins of calcite crisscrossing the stone (Boulvain \& Pingot 2013) are distinctly different than the black Dębnik limestones with very sparse and hardly seen fauna of hydrozoans Amphipora sp. and Stromatophora sp., accompanied by minor corals, gastropods, brachiopods, pelecypods and crinoids.

Table 2

Names and macroscopic characteristics of the black "marbles" used in the Polish architecture

\begin{tabular}{|c|c|}
\hline Name of stone $e^{\star}$ & Hand specimen characteristics \\
\hline $\begin{array}{l}\text { Noir Belge } \\
\text { Marbre Noir de Golzinne } \\
\text { Noir de Mazy } \\
\text { also known as (or varieties): } \\
\text { Golzinne black marble } \\
\text { Noir Fin }\end{array}$ & $\begin{array}{l}\text { homogenous, fine-grained, almost perfect deep black color, } \\
\text { without macrofossils and calcite veins }\end{array}$ \\
\hline $\begin{array}{l}\text { Noir de Dinant } \\
\text { Marbre Noir de Dinant } \\
\text { also known as (or varieties): } \\
\text { Noir de Denée } \\
\text { Noir de Salet }\end{array}$ & $\begin{array}{l}\text { homogenous, fine-grained, deep black color, sometimes } \\
\text { with white calcite fragments of fossils (mainly crinoids and } \\
\text { foraminifera) }\end{array}$ \\
\hline $\begin{array}{l}\text { Bleu Belge } \\
\text { also known as (or varieties): } \\
\text { Belgian Bleu } \\
\text { Noir veine marbre }\end{array}$ & $\begin{array}{l}\text { fine-grained, dark blue-black with calcite veins intersecting } \\
\text { the rock in all directions }\end{array}$ \\
\hline $\begin{array}{l}\text { Calcaire de Meuse } \\
\text { Calcaire de Meuse - Vinalmount } \\
\text { also known as (or varieties): } \\
\text { Pierre de Vinalmount } \\
\text { Meuse stone } \\
\end{array}$ & $\begin{array}{l}\text { dark gray to brown, very uniform in appearance, with } \\
\text { characteristic oolites arranged in slightly interlaced } \\
\text { stratifications and white calcite fossils of foraminifera }\end{array}$ \\
\hline $\begin{array}{l}\text { Noir de Tournai } \\
\text { also known as (or varieties): } \\
\text { Banc Bleu } \\
\text { Noir Childeric } \\
\text { Noir Clovis }\end{array}$ & $\begin{array}{l}\text { fine-grained, dark gray to black, more difficult to scratch } \\
\text { than pure limestone because is slightly silicified, white calcite } \\
\text { fossils of bryozoans }\end{array}$ \\
\hline $\begin{array}{l}\text { Petit granit } \\
\text { Pierre bleue de Belgique } \\
\text { Belgian blue limestone } \\
\text { also known as (or varieties): } \\
\text { Blue stone } \\
\text { Petit granit du Bocq }\end{array}$ & $\begin{array}{l}\text { medium-grained, gray, bluish gray, nearly black, often spotted } \\
\text { with white calcite fossils (crinoids, bryozoans, brachiopods) }\end{array}$ \\
\hline
\end{tabular}


Table 2 cont.

\begin{tabular}{|l|l|}
\hline \multicolumn{1}{|c|}{ Name of stone* } & \multicolumn{1}{|c|}{ Hand specimen characteristics } \\
\hline Pierre de Tournai & $\begin{array}{l}\text { fine-grained, gray, more difficult to scratch than pure } \\
\text { limestone because is slightly silicified, white calcite fossils of } \\
\text { bryozoans }\end{array}$ \\
\hline $\begin{array}{l}\text { Dębnik limestone } \\
\text { Dębnik marble } \\
\text { also known as (or varieties): } \\
\begin{array}{l}\text { Schwarzer Marmor von Dembnik Korallenkalk von Siedlec } \\
\text { Schichten der Siwa Góra } \\
\text { Amphipora-Banke des Karmeliterbruches der Czarna Góra }\end{array}\end{array}$ & $\begin{array}{l}\text { homogenous, fine-grained, black or nearly black color, } \\
\text { sometimes fossils (gastropods, corals, hydrozoans) and/or } \\
\text { thin calcite veins are present, also characteristic concentric } \\
\text { structure in various shades of gray; inferior varieties: not } \\
\text { homogeneous, black and dark gray detrital, nodular and } \\
\text { laminated limestones }\end{array}$ \\
\hline Kajetanów limestone & $\begin{array}{l}\text { homogenous, fine-grained, uniform black or nearly black, } \\
\text { sometimes presence of brachiopods and also dark gray } \\
\text { variety with calcite veinlets }\end{array}$ \\
\hline
\end{tabular}

* The names of stones from Netherlands (present-day Belgium) are based on the literature cited in the paper and web pages: The Association Pierres et Marbres de Wallonie (on-line); Stone Quarries and Beyond compiled by Perazzo \& Perazzo (2013, on-line) and of Belgium National Commission on Stratigraphy (on-line).

** Because to fracturing the rock is not considered as being of economic significance.

Also, the Petit Granit limestone (packstone to grainstone), with a texture resembling that of granite as its name implies (Petit Granit = "little granite") and numerous, millimeter-large bioclasts of main crinoids (Dreesen et al. 2007) distinctly differs from the Dębnik limestone. One of the Dębnik limestone varieties is easily recognizable due to characteristic nodular texture and wavy bedding, with marly streaks separating its nods and wavy beds. The network of calcite veins in the Dębnik limestones is never so dense as that in the Bleu Belge variety. In turn, the Noir de Tournai limestone and the lighter Pierre de Tournai (both wackstones/packstones) from the Schelde River area due to their silicification are harder than the Dębnik limestone and have fine bioclasts of bryozoans, distinctly seen against the darker background of these rocks (Barquin et al. 2006, Hance et al. 2006, Storemyr et al. 2007).

The Polish black limestones from Kajetanów in the Holy Cross Mountains are pelitic with uniform black color and characterized by the presence of brachiopods and bryozoans identifiable under the microscope. Two other limestones, i.e., from Łagów and Górno also in the Holy Cross Mountains, have been mentioned here only to keep the record straight: the former are in fact brown-colored (Święcicki 1874, Kotański 1959, Kowalczewski 1972), the latter form beds too thin to be used in blocks (Czarnocki 1952, Wardzyński 2012). Considering the domination of the Dębnik stones in the Polish small-scale, baroque architecture, the rocks from the Holy Cross Mountains are of marginal significance.

A problem may arise in distinguishing the uniform, deeply black, pelitic Noir Belge limestones without macrofossils and calcite veins from the homogenous, micritic limestone variety of the Dębnik stone. The resemblance of these two and the lack of detailed analyses have resulted most probably in different identifications of the stones used in the chapel of the Kołudzki family in the Gniezno cathedral (see Introduction). The microscopic characteristics would be helpful here, as the Noir Belge rock is a mudstone sensu Dunham (1962), containing very sparse fossils of echinoids, ostracods, pelecypods, sponges and algae, while the Dębnik rock in the same classification is a wackstone and contains differing fossils of hydrozoans (Amphipora sp. and Stromatophora sp.), corals, brachiopods, pelecypods and gastropods. Other hints could be provided by comparing the results of phase and chemical analyses (major and even minor and trace elements) and stable isotope $\left({ }^{13} \mathrm{C}\right.$ and ${ }^{18} \mathrm{O}$ ) determinations. The Noir Belge rocks represent practically pure limestones as they contain major calcite and traces of bitumens (Groessens 1997, Barquin et al. 2006, Coen-Aubert \& Boulvain 2006, Devleeschouwer et al. 2012), while the Dębnik rock, although also classified as pure limestone, has a non-carbonate admixture of bitumens, pyrite, clay minerals and others. Therefore, differences in chemical analyses would be 
obvious and indicative. Unfortunately, there are no isotope data for the Noir Belge black limestone to compare with the author's isotope analyses. In the case of the Netherlandish black limestones, only found in the literature were the data on the isotopic composition of the well-preserved shells of brachiopods from the Dinantian (Tournaisian and Visean) strata and the Devonian-Carboniferous boundary sequence of the Namur-Dinantian Basin in southern Belgium (e.g. Bruckschen \& Veizer 1997, Azmy et al. 2009). Early limestone studies were carried out on whole rock samples, but later on individual components, such as shells and various generations of rock cements (Hofes 2009). For determining the provenance of black limestones considering the differences of their isotopic composition, data for whole samples are necessary.

Referring to the remaining types of the Netherlandish limestones, additional mineralogical and petrographical investigations, chemical analyses or isotope determinations do not seem to be necessary to identify these rocks within their group and to distinguish them from the Polish Dębnik limestones. The differences in the fossilized fauna mentioned above (generally Visean limestones from the Meuse River area are rich in foraminifera, the Tournaisian limestones from the Schelde River area contain bryozoans; the Givetian limestones from Dębnik have mainly fossils of hydrozoans, brachiopods and corals) as well as the characteristic textures of some rocks (e.g. the oolitic Calcaire de Meuse - Vinalmount) are features sufficiently diagnostic to identify specific limestones. Almost all the limestones discussed have high contents of $\mathrm{CaCO}_{3}$ (95-99\%) except for the Noir de Tournai and Pierre de Tournai rocks. The limestones from the Tournai region in the Schelde River area have distinctly less $\mathrm{CaCO}_{3}, 75-80$ wt. \%, which is their diagnostic trait.

Establishing differences in the mineral composition of non-carbonate components is not easy. Due to their low contents, they often cannot be spotted in perfunctory observation and require detailed checks. Even after concentrating in $\mathrm{HCl}$-insoluble fractions they are difficult to be optically identified because of their micro- to cryptocrystalline development and, in some cases, possible masking by organic and clay substances. $\mathrm{X}$-ray diffractometry may be thus of some help. In this respect, certain similarities reveal the Noir de Tournai, Pierre de Tournai limestones and those from Dębnik (especially nodular and laminated variety of the latter), mainly because of the presence of clay minerals and pyrite.

Lack of literature data on the detailed mineralogy and chemistry of the limestones from the Holy Cross Mountains makes impossible their comparison with the remaining rocks in question.

The signs of weathering seen as bleaching of polished artifacts and decoloration of natural stones exposed first of all to the external atmospheric factors cannot be a diagnostic differentiation criterion. Similar changes are observed in the case of limestone of the Netherlands and Dębnik.

The effects of graying or whitening of the stone surface in the case of the Dębnik limestones are widely observed both in outcrops and architectonic artifacts (Kozłowski \& Magiera 1989, Wilczyńska-Michalik 2004, Marszałek et al. 2006, Marszałek 2007, 2008, Marszałek \& Skowroński 2010). Superficial graying (or whitening) of the limestone exposed to a polluted, urban atmosphere is combined with deposition of anthropogenic particulates on the stone surfaces. As a result, architectonic elements are covered with micro- to cryptocrystalline gypsum containing particles of dust, mainly aluminosilicate glass spherules and iron oxides; all of them form the so-called false patina. The presence of this layer makes an explanation of the color alterations additionally difficult. A commonly voiced reason of such changes is weathering (oxidation) of the organic compounds of limestones. The organic matter, particularly aromatic hydrocarbons, is the least stable carbon pigment. Nevertheless, the reasons for the chromatic weathering, i.e. whitening or graying, are not clear-cut.

The presence of microfractures within the near-surface layer of the weathered Dębnik limestones may suggest another genesis of the rock whitening, based on optical phenomena. The light is mostly dispersed in various directions by their porous surfaces and scattered by grain boundaries and internal microfractures of grains. Grain fracturing may be explained as a result of cracking calcite crystals caused by their anisotropic expansion as there are differences between the 
thermal expansion coefficients along the $a$ and $c$ lattice directions (Marinoni et al. 2007). Another suggestion is that the stress resulting from oscillation of ambient temperatures that start at about $40-60^{\circ} \mathrm{C}$ can cause microfractures among and within mineral grains (Winkler 1997, Marinoni et al. 2007). As a result, the surface takes the white color, typical of the disintegrated, powder material known to mineralogists as the streak. The last explanation additionally indicates that one of the decorating techniques of the Dębnik limestone ("manière criblée" or "graining") seems to confirm this latter micromechanical reason for stone bleaching (Fig. 6C). Mastered by the renown Zielaski family of mason-sculptures from Dębnik, this highly sophisticated stone engraving technique is based on combining two contrasting surfaces, one concave, matt and hammered into a pea-like pattern, and another polished and convex (Tatarkiewicz 1953, Wiloke \& Thunig 1987, Niemcewicz 2005).

Re-polishing and treating the bleached stone surface with fat restores the luster and the black color of architectonic elements (Tatarkiewicz 1953, Niemcewicz 2005). The last phenomenon results from filling the pores with a medium of similar optical properties as those of the minerals of the stone, for instance with the linseed oil, whose index of refraction 1.48 is close to one of the calcite indices of refraction $\left(n_{\varepsilon}=1.486\right.$ and $\left.n_{\omega}=1.658\right)$.

Additionally, some differences in stone damage that depend on the texture of the Dębnik limestone variety and its orientation to bedding have been observed. The elements cut out of the stones without sedimentary textures, i.e., the micritic limestones and the micritic limestones with fauna, are more resistant (Niemcewicz 2005, Marszałek 2007).

\section{CONCLUSIONS}

Detailed search queries carried out lately in different disciplines of science, including the history of economics and economic geology, have provided a whole range of information on the import and use of building and decorative stones in the Polish lands in the $17^{\text {th }}$ and $18^{\text {th }}$ centuries. Besides the domestic Devonian limestones from Dębnik near Krakow, equally popular were the
Netherlandish (present-day Belgium), Upper Devonian to Lower Carboniferous limestones from the Meuse River and Schelde River valleys. Distinguishing among the black limestones from the Meuse and Schelde regions and those from Dębnik may not be very complicated from the point of view of hand specimen petrography. Most of these stones (the Noir de Dinant, Bleu Belge, Calcaire de Meuse - Vinalmount, Noir de Tournai, Pierre de Tournai and Petit Granit) reveal diagnostic macroscopic features, e.g. textures, different type of fossils, hardness (Tab. 2). In the case of limestones without such clear-cut differences, for instance the Noir Belge and the homogenous micritic Dębnik variety, some methods typical of the Earth sciences, particularly petrographic investigations in thin sections, may provide data of a significant identification value. Unfortunately, petrographic studies need larger samples, preferably approximating $1 \mathrm{~cm} \times 1 \mathrm{~cm}$, which are of limited availability, thus only occasionally can be obtained from historical works of art. Considering the latter limitation, the methods that could help in stone identification seem to be mainly chemical (major, but even minor and trace elements) and isotopic $\left({ }^{13} \mathrm{C}\right.$ and $\left.{ }^{18} \mathrm{O}\right)$ determinations. The carbon and oxygen stable isotope analyses need very small samples and if their result plot within non-overlapping areas on the provenance diagrams, the field location of the parent rock may be obvious and easily obtained. As the isotope and chemical determinations of the Netherlandish Noir Belge limestones have not been found, their investigations should follow in a future. If initial data show that the fields of isotope variability of the Dębnik and Noir Belge limestones do not overlap, the range of isotope analyses could be extended in the future and applied to limestones collected from historic sites. Even in such a case, their combination with petrographic investigations is recommended to obtain a required degree of accuracy.

With regard to the Kajetanów limestones from Poland, which have not been the subject of detailed investigations, it would also be desirable to include at least single samples into a future study. However, such an attempt would require obtaining special permission as the quarry at Kajetanów has the status of a monument of the inanimate nature. 
This work was financially supported by the AGH University of Science and Technology (grant no. 11.11.140.319).

The author acknowledges the help of J. Czerny in fieldwork. My thanks also go to A. Gawet and $Z$. Klimek for help in carrying out XRF analyses, T. Szydłak for discussion and A. Skowroński for discussions and language correcting. The author would like to thank both Reviewers for valuable criticism, comments and suggestions, which have shaped the final manuscript version.

\section{REFERENCES}

Anderson F. \& Groessens E., 1996. The black altars of Nehalennia. Oudheidkundige mededelingen uit het Rijksmuseum van oudheden te Leiden, 76, 129-138.

Azmy K., Poty E. \& Brand U., 2009. High resolution isotope stratigraphy of the Devonian -Carboniferous boundary in the Namur-Dinant basin, Belgium. Sedimentary Geo$\log y, 216,3-4,117-124$.

Baliński A., 1989. Biostratygrafia górnego dewonu antykliny Dębnika. [in:] Rutkowski J.(red.), Przewodnik LX Zjazdu PTG, Kraków, 30-34.

Barquin F., Nicaise D. \& Bams V., 2006. Pierres naturelles (NIT 228). Le Centre Scientifique et Technique de la Construction. [on-line:] http://www.cstc.be [accessed : 20 January 2014].

Bednarczyk J. \& Hoffman M., 1989. Wapienie dębnickie. [in:] Rutkowski J. (red.), Przewodnik LX Zjazdu PTG, Kraków, 40-46.

Belgium National Commission on Stratigraphy, [on-line:] http://ncs.drupalgardens.com [accessed: 20 January 2014].

Benavente D., Bernabéu A., Fort R., Martínez-Martínez J. \& García del Cura M.A., 2006. The decoloration of brecciated black marbles used in heritage monuments of Alicante. [in:]

Fort R., Alvarez de Buergo M., Gomez-Heras M. \& Vazquez-Calvo C. (eds), Heritage, Weathering and Conservation, Taylor \& Francis, London, 1, 205-210.

Boulvain F. \& Pingot J-L., 2013. Une introduction á la Geologie de la Wallonie. [on-line:] http://www2.ulg.ac.be/geolsed/geolwal/geolwal.htm [accessed: 20 January 2014].

Brilli M., Antonelli F., Giustini F., Lazzarini L. \& Pensabene P., 2010. Black limestones used in antiquity: the petrographic, isotopic and EPR database for provenance determination. Journal of Archeological Science, 37, 994-1005.

Brilli M., Conti L., Giustini F., Occhiuzzi M., Pensabene P. \& De Nuccio M., 2011. Determining the provenance of black limestone artifacts using petrography, isotopes and EPR techniques: the case of the monument of Bocco. Journal of Archeological Science, 38, 1377-1384.

Bruckschen P. \& Veizer J., 1997. Oxygen and carbon isotopic composition of Dinanatian brachiopods. Paleoenvironmental implications for the Lower Carboniferous of western Europe. Paleogeography, Paleoclimatology, Paleoecology, 132, 243-264.
Bromowicz J., 2001. Ocena możliwości wykorzystania skał $\mathrm{z}$ okolic Krakowa do rekonstrukcji kamiennych elementów architektonicznych. Gospodarka Surowcami Mineralnymi, 17, 1, 16-73.

Bromowicz J. \& Figarska-Warchoł B., 2012. Kamienie dekoracyjne i architektoniczne południowo-wschodniej Polski - złoża, zasoby i perspektywy eksploatacji. Gospodarka Surowcami Mineralnymi, 28, 3, 5-16.

Coen-Aubert M. \& Boulvain F., 2006. Frasnian. Geologica Belgica, 9, 1-2, 19-25.

Czarnocki J., 1923. Cechsztyn w Górach Świętokrzyskich. Sprawozdania Polskiego Instytutu Geologicznego, 2, 1-2, 150-197.

Czarnocki J., 1952. Marmury świętokrzyskie. [in:] Materiały do znajomości skat w Polsce, Biuletyn 80, Państwowy Instytut Geologiczny, Warszawa, 27-48.

Czarnocki J., 1965. Stratygrafia Gór Świętokrzyskich. Karbon i perm. [in:] Pawłowska K. \& Pawłowski S. (eds), Prace Geologiczne, 42, 1, 4, Prace Instytutu Geologicznego, Wydawnictwa Geologiczne, Warszawa.

Devleeschouwer X., Sotiriou C. \& Fournier L., 2012. The black marble of Mazy (Belgium): a multi-proxy approach on anoxic Frasnian limestone. $4^{\text {th }}$ International Geologica Belgica Meeting. Moving Plates and Melting Icecaps. Processes and Forcing Factors in Geology, Abstract Book, Brussels 11-14 September 2012, [on-line:] http://www.geologicabelgica.be/PDF/GB/ S4/P_S4_3_Devleeschouwer.pdf [accessed: 20 January 2014].

Devuyst F.X., Hance L. \& Poty E., 2006. Moliniacian. Geologica Belgica, 9, 1-2, 123-131.

Dreesen R., Neilsen P. \& Lagrou D., 2007. The staining of the blue stone limestones petrographically unraveled. Materials Characterization, 58, 1070-1081.

Dunham R.J., 1962. Classification of carbonate rocks according to depositional texture. [in:] Ham W.E. (ed.), Classification of carbonate rocks [series: AAPG Memoir, 1], AAPG, Tulsa OK, 108-210.

Fraaye R.H. \& Werver O.P., 1990. Trace fossils and their environmental significance in Dinantian carbonates of Belgium. Palaontologie, 64, 3/4, 367-377.

Gradziński R., 1972. Przewodnik geologiczny po okolicach Krakowa. Wydawnictwa Geologiczne, Warszawa.

Groessens E., 1993. L'origine et l'évolution de l'expression "Petit-granit". Bulletin de la Société Belge de Géologie, 102, 271-276.

Groessens E., 1997. Le marbre noir. [in:] Toussaint J., Boiseries et marbres sculptés en Namurois [series: Monographies du Muséee des Arts anciens du Namurois], Société archéologique de Namur, Namur, 67-73.

Groessens E., 2001a. La géologie et le petit-granit. Bulletin du Groupe d'Etude des Sciences de la Terre, 110, 2-19.

Groessens E., 2001b. La calcaire de Meuse, un matériau belge exporté depuis les Romains. Carrières et Constructions, $4,155-172$.

Hance L., Poty E. \& Devuyst F.X., 2006. Tournaisian. Geologica Belgica, 9, 1-2, 47-53.

Hudson J.D., 1977. Stable isotopes and limestone lithification. Journal of Geological Society of London, 133, 6, 637-660.

Hofes J., 2009. Stable isotope geochemistry. Springer, Berlin - Heidelberg. 
Kirnbauer T., 2008. Nassau marble (Nassauer Marmor) or Lahm Marble (Lahnmarmor) - a famous Devonian dimension stone from Germany. [in:] Siegiesmund S. \& Snethlage R. (eds), Denkmalgesteine - Festschrift Wolf-Dieter Grimm, Schriftenreihe der Deutschen Gesellschaft für Geowissenschaften, Hannover, 59, 187-218.

Kotański Z., 1959. Przewodnik geologiczny po Górach Świętokrzyskich. Wydawnictwa Geologiczne, Warszawa.

Kowalczewski S., 1972. Marmury kieleckie. Państwowe Zakłady Wydawnictw Szkolnych, Warszawa.

Kozłowski R. \& Magiera J., 1989. Niszczenie wapieni dębnickich i pińczowskich w zabytkach Krakowa. [in:] Rutkowski J. (red.), Przewodnik LX Zjazdu PTG, Kraków, 204-208.

Kozłowski S., Mojsiejenko A., Rogaliński J., Rubinowski Z., Wrona H. \& Żak C., 1971. Surowce mineralne województwa kieleckiego. Wydawnictwa Geologiczne, Warszawa.

Le Centre Scientifique et Technique de la Construction, [on-line:] www.cstc.be [accessed : 20 January 2014].

Lesse M.N., 1988. Statistical treatment of stable isotope data. [in:] Hertz N. \& Waelkens M. (eds), Classical Marble: Geochemistry, Technology, Trade, Dordrecht - London Boston, 347-354.

Lewandowska A., 1998. Mineralogia skarnów magnezowych grzbietu Dębnika. Uniwersytet Jagielloński, Kraków [Ph.D. thesis].

Marinoni N., Pavese A., Bugini R. \& Di Silvestro G., 2002. Black limestone used in Lombard architecture. Journal of Cultural Heritage, 3, 241-249.

Marinoni N., Pavese A., Riva A., Cella F. \& Cerulli T., 2007. Chromatic weathering of black limestone quarried in Varenna (Lake Como, Italy). Building and Environment, 42, 68-77.

Marszałek M., 2007. Mineralogical and chemical methods in investigations of decay of the Devonian black "marble" from Dębnik (S Poland). [in:] Přikryl R. \& Smith B. (eds), Building Stone Decay: from Diagnosis to Conservation, Geological Society, London, 109-115.

Marszałek M., 2008. Application of optical microscopy and scanning electron microscopy to the study of the stone weathering: a Cracow case study. International Journal of Architecture Heritage. Conservation, Analysis and Restoration, 2, 1, 83-92.

Marszałek M. \& Muszyński M., 2001. Authigenic K-feldspars in Dębnik limestone (S Poland). Mineralogia Polonica, 32, 1, 49-61.

Marszałek M. \& Skowroński A., 2010. Black "marble": the characteristic material in Baroque architecture of Cracow (Poland). [in:] Bostenaru Dan M., Prrikryl R. \& Török A. (eds), Materials, Technologies and Practice in Historic heritage Structures, Springer, Berlin, 93-107.

Marszałek M., Skowroński A. \& Gaweł A., 2006. Składniki antropogeniczne $\mathrm{w}$ zwietrzałych wapieniach dębickich z krakowskich zabytków. Gospodarka Surowcami Mineralnymi, 22, 3, 450-459.

Mottequin B., 2004. Paléoécologie et interprétation sédimentologique du "Marbre Noir" de Denée (Viséen Inférieur, Belgique). Geologica Belgica, 7, 1-2, 3-19.

Mottequin B., 2008. The 'black marble' of Denée, a fossil conservation deposit from the Lower Carboniferous (Viséan) of southern Belgium. Geological Journal, 43, 197-208.
Mrázek I., 1993. Kamenná tvář Brna. Moravské zemské muzeum, Brno.

Narkiewicz M. \& Racki G., 1984. Stratygrafia dewonu antykliny Dębnika. Kwartalnik Geologiczny, 28, 3-4, 513-546.

Natural stone - denomination criteria, 2007. [on-line:] http:// febenat.wdfiles.com/local--files/normen/prEN\%20 12440-2007\%20\%28EN\%29\%20Natuursteen\%20 benamingscriteria.pdf [accessed: 12 September 2013].

Niemcewicz P., 2005. Konserwacja wapienia dębnickiego. Wydawnictwo Uniwersytetu Mikołaja Kopernika, Torun.

Nijs R.,1992. Natural building stones in Flanders. Mineralogia Polonica, 23, 1, 62-72.

Pintér F., Szamány G., Demény A. \& Tóth M., 2004. The provenance of "red marble" monuments from the $12^{\text {th }}-18^{\text {th }}$ centuries in Hungry. European Journal of Mineralogy, 16, 619-629.

Perazzo P. \& Perazzo G., 2013. Stone Quarries and Beyond. [on-line:] http://quarriesandbeyond.org/index.html [accessed: 20 February 2014].

Peszat C., 1980. Własności fizyczno-mechaniczne skał węglanowych dewonu Gór Świętokrzyskich. Biuletyn Instytutu Geologicznego, 324, 283-319.

Polikreti K., Maniatis Y., Bassiakos Y., Kourou N. \& Karageorghis V., 2004. Provenance of archaeological limestone with EPR spectroscopy: The case of the Cypriote-type statuettes. Journal of Archaeological Science, 31, 1015-1028.

Rajchel J., 2004. Kamienny Kraków. Spojrzenie geologa. Uczelniane Wydawnictwa Naukowo-Dydaktyczne AGH, Kraków.

Spoetl C. \& Vennemann T.W., 2003. Continuous-flow isotope ratio mass spectrometric analysis of carbonate minerals. Rapid Communications in Mass Spectroscopy, 17, 1004-1006.

Storemyr P., Degryse P. \& King J.F., 2007. A black Tournai "marble" tombslab from Belgium imported to Trondheim (Norway) in the $12^{\text {th }}$ century. Provenance determination based on geological, stylistic and historical evidence. Materials Characterization, 58, 1140-1118.

Sylwestrzak H. \& Kachnic J., 2010. Kamienne tworzywo sztuki. Wydawnictwo Naukowe Uniwersytetu Mikołaja Kopernika, Toruń.

Święcicki H., 1874. Opis marmurów krajowych mianowicie przesłanych na wystawę w Moskwie i Wiedniu. [in:] $\mathrm{Pa}$ miętnik kielecki na rok zwyczajny 1874, 47-55.

Szmydki R., 1999. Niderlandzcy kamieniarze angażowani przez Zygmunta III (w pierwszej ćwierci XVII wieku). Kronika Zamkowa, 2, 38, 45-66.

Szmydki R., 2000. Południowoniderlandzkie marmury w Zamku Królewskim w Warszawie za Zygmunta III. Kronika Zamkowa, 2, 40, 5-17.

Szmydki R., 2012. Les marbres belges dans les demeures royales en Pologne au XVII ${ }^{\mathrm{e}}$ siècle. Bulletin du Centre de recherche du château de Versailles. [on-line:] http://crcv. revues.org/11991 [accessed: 20 January 2014].

Tatarkiewicz W., 1953. Czarny marmur w Krakowie [series: Prace Komisji Historii Sztuki, 10]. Polska Akademia Umiejętności, Kraków.

The Association Pierres et Marbres de Wallonie, [on-line:] http://www.stonesandmarbles.be [accessed: 20 January 2014]. 
Tołkanowicz E., 2001. Marmury Polskie. Świat Kamienia, 4 , 15-20.

Wardzyński M., Marmur i alabaster jako materiały kamieniarskie i rzeźbiarskie w sztuce polskiej doby nowożytnej. Wprowadzenie do tematu. [on-line:] http://www.fundacja-hereditas.pl/portal/files/konserwacja_kamienia_ MWardzynski.pdf [accessed: 20 January 2014].

Wardzyński M., 2008. Marmury i wapienie południowoniderlandzkie na ziemiach polskich od średniowiecza do 2. poł. XVIII w. Import i zastosowanie w małej architekturze i rzeźbie. Biuletyn Historii Sztuki, 70, 3-4, 307-358.

Wardzyński M., 2010. Marmury południowoniderlandzkie i alabaster angielski w małej architekturze i rzeźbie sakralnej i sepulkralnej 1. poł. XVII w. w Warszawie. [in:] Michalczyk Z., Pieńkosa A. \& Wardzyński M. (eds), Kultura artystyczna Warszawy XVII-XXI w., Neriton, Warszawa, 43-58.

Wardzyński M., 2012. Artifices Chencinenses. Rola i miejsce warsztatów chęcińskich w produkcji kamieniarsko- -rzeźbiarskiej w Rzeczypospolitej (koniec XVI - 1. połowa XVII w.). [in:] Kalina D., Kubicki R. \& Wardzyński M. (eds), Franciszka z Krasińskich Wettyn: księżna Kurlandii i Semigalii, prababka dynastii królów włoskich: dziedzictwo rodziny Krasińskich $w$ regionie świętokrzyskim, Urząd Marszałkowski Województwa Świętokrzyskiego, Kielce - Lisów, 151-184.

Wiloke H. \& Thunig W., 1987. Kamieniarstwo. Wydawnictwa Szkolne i Pedagogiczne, Warszawa.

Wilczyńska-Michalik W., 2004. Influences of atmospheric pollution on the weathering of stones in Cracow monuments and rock outcrops in Cracow, Cracow-Częstochowa Upland and the Carpathians [series: Prace Monograficzne, 377]. Akademia Pedagogiczna w Krakowie, Kraków.

Winkler E.M., 1997. Stone in Architecture. Properties, durability. Springer, Wien - New York.

Zehnder K., 2006. Graying of black polished limestone - a case study to clarify the phenomenon. Zeitschrift fur Kunsttechnologie und Konservierung, 2, 361-367. 